\title{
Persistence of viral RNA in the brain of experimentally infected mice with coxsackievirus B5
}

\author{
D. Stipalova ${ }^{1}$, M. Sojka ${ }^{1}$, M. Borsanyiova ${ }^{1}$, M. Badurova ${ }^{1}$, \\ L. Marosova ${ }^{1}$, Z. Sobotova $^{2}$, S. Bopegamage ${ }^{1}$ \\ ${ }^{1}$ Department of Virology, Slovak Medical University \\ ${ }^{2}$ National Reference Centres, Public Health Office of the Slovak Republic \\ 52, Trnavska St., Bratislava, Slovak Republic, 82645 \\ darina.stipalova@szu.sk
}

\begin{abstract}
Aim. The aim of our study was to follow the persistence of viral RNA in selected organs of experimentally infected with coxsackievirus (CV) B5 strains from different sources such as a patient's sample, an environmental sample and a prototype virus strain. Methods. CD-1 mice were infected with CVB5 strain Faulkner the prototype, CVB5 - isolate from treated sewage waste and isolate from patient's stool sample both identified as CVB5. The viral RNA was detected by RT-PCR using enterovirus primers specific for the non-coding 5' region. Results. We observed presence of RNA in the brain and heart of mice infected with isolate from patient's stool at day 45 post infection (p. i.). Conclusion. We conclude that CVB5 persists in the brain and heart after oral infection of CDI mice. The relevance of viral persistence maybe related viral origin and the genetics.

Keywords: coxsackievirus B5, mouse, brain, persistence.
\end{abstract}

Introduction. Coxsackievirus B5 (CVB5) belongs to the genus Enterovirus and the family Picornaviridae. Epidemiological data have shown that this serotype is one of the most frequently isolated enteroviruses from infected humans [1].

CVB5 is associated often with meningitis, sporadic cases of neurological diseases, and chronic diseases such as cardiomyopathy and diabetes. Coxsackievirus and echovirus are frequent causes of aseptic meningitis, particularly in children, but are rarely life threatening. Fatality has been reported as in a case of meningoencephalitis [2], in immunosuppressed patient.

These viruses exist as circulating heterogeneous virus populations of genetic variants as other enteroviruses. Mice are used for studying pathogenesis of coxsackieviruses due to the presence of mouse coxsackie-adenovirus receptor (mCAR) which exists on cells of different organs.

Our aim was to study the persistence of viral RNA in different organs of experimentally infected mice.

(c) Institute of Molecular Biology and Genetics NAS of Ukraine, 2011
Materials and methods. Virus and cells. CVB5 (Faulkner) was obtained from the former National Institute of Health, Prague, Czech Republic, and propagated in Green monkey kidney (GMK) cells. S1 B5 (identified as CVB5) - isolate from the interphase formed during sewage treatment and S2 B5 (identified as CVB5) - isolate from patient's stool sample. GMK cells were used for virus propagation and titrations. Cells were grown in Eagle's minimum essential medium $(\mathrm{MEM}(\mathrm{E}))$ supplemented with $10 \%$ heat inactivated bovine serum $\left(\right.$ at $\left.56^{\circ} \mathrm{C}\right)$ for cell growth and 5 or $2 \%$ serum for maintenance and infection. For plaque purification the double layer technique was used. The method was standardized in our laboratory, details have been described by Motusova et al. [3].

Selected virus plaques were picked up and suspended in $0.5 \mathrm{ml} \mathrm{MEM(E)} \mathrm{and} \mathrm{used} \mathrm{for} \mathrm{further} \mathrm{stock} \mathrm{prepa-}$ rations and studies.

Virus isolations from organs and stools were checked as described previously [4] in Hep2 cells.

Mice. CD1 3-4 weeks old (10-12 g) were acquired from HARLAN (Italy). Mice were housed two or three 
per cage and supplied with sterile water and commercial food pellets (Topdovo). Permission for the animal work was obtained from the Ethics Committee of the Slovak Health University and the State Veterinary and Food Control Authority of the Slovak Republic.

Oral infection. Oral infection of mice has been described previously $[4,5]$. Mice were divided into four groups of 20 mice. Each group received $0.5 \mathrm{ml}$ virus suspension or PBS (uninfected controls). The virus dose used for inoculation was $10^{7} \mathrm{TCID}_{50}$ of each CVB5 (Faulkner), S1 B5 CVB5 - isolate from the interphase of treated sewage sample and S2 B5 CVB5 - isolate from patient's stool sample. Mice were sacrificed and organs (heart, pancreas, brain) were collected from each group of 5 infected mice/group and 5 control mice/ group at days 5,10 and 45 post infection. Organs were collected separately; snap frozen and stored at $-80{ }^{\circ} \mathrm{C}$.

$P C R$ analysis. RNA was extracted from snap-frozen organs (heart, brain, pancreas) with a Mammalian Total RNA kit («Invitrogen», USA). cDNA synthesis and cDNA amplification were performed by using a single tube method with The SuperScript III One-Step RT-PCR System with Platinum Taq High Fidelity ( «Invitrogen») as has been described $[4,6]$. Nested RTPCR was done. Primers used were targeted to the 5' non-coding region as described by de Leeuw et al. [6] and Bopegamage et al. [4].

Results and discussion. In the present study we have studied the presence of viral RNA in organs of CD1 outbred mice infected by three different CVB5 strains (patient's isolate and an isolate identified as CVB5 from treated sewage sample and the prototype strain). Viral RNA was detected in the brain and heart of mice infected with isolate from patient's stool at day 45 p. i. (Table), replicating virus was not isolated at this period in any of the organs at this time period. The latest interval studied by us previous to the day $45 \mathrm{p}$. i. was day $10 \mathrm{p}$. i. when the replicating virus is usually isolated. At day 10 p. i. maximum positives were found in mice infected with the isolate from patient's stool S2 B5 CVB5. Presence of viral RNA in the brain in an experimental model has not been studied previously. A single positive mouse for viral RNA can be explained due to the outbred mice used by us. Prolonged presence of viral RNA in a single mouse in the late phases after infection is common.

In our previous study [4], we had shown prolonged presence of viral RNA in the pancreas and small in-
Presence of viral RNA in organs of orally infected CD1 outbred mice at day 45 p. $i$.

\begin{tabular}{c|c|c|c}
\hline Virus & Heart & Pancreas & Brain \\
\hline CVB5 & $0 / 5$ & $0 / 5$ & $0 / 5$ \\
S1 B5 & $0 / 5$ & $0 / 5$ & $0 / 5$ \\
S2 B5 & $1 / 5 * *$ & $0 / 5$ & $1 / 5$ \\
\hline
\end{tabular}

CVB5* - Coxsackievirus B5 strain Faulkner (prototype virus); S1 B5 - isolate from treated sewage sample identified as CVB5 labeled as $\mathrm{S} 1$; S2 B5 - isolate from patient's stool identified as CVB5 labeled as $\mathrm{S} 2$; **number of organs positive for viral RNA/total number of organs tested.

testine of Swiss outbred mice infected orally by CVB3 (Nancy strain) given at different doses. CVB infection and persistence of viral RNA leading to direct damage of the cardiomyocytes have been studied by Andreoletti et al. [7], Kandolf et al. [8], and Klingel et al. [9] who have used inbred A/J mice. CVB3 persistence and inbred mouse strains has been reviewed by Chapman and Kim [10] and Klingel [11]. Persistence of the viral RNA in the brain of experimentally infected mice by any CVB has not been studied before. In the last few years in humans the persistent enteroviruses have been suspected to be the cause of various central nervous system (CNS) and muscle disorders of unknown etiology, including motor neurone disease, post-polio syndrome, the chronic fatigue syndrome [12]. The mechanism of viral persistence for enterovirus is not known. The suggested mechanisms include mutations from lytic to non-lytic or defective mutants and change in cell tropism [13], and the asymmetrical ratio of plus to minus strand RNA by Tracy [14]. Furthermore mutations in the stem loop II of the 5 ' non coding structure has been suggested by Dunn et al. [15]. Our observations could be explained as to the difference in the virus strains, even within the 5 mice in that particular group to the outbred model used by us. Sequencing of the persistent RNA from the organs and comparison to the original viral RNA is required to be studied further.

Conclusion. We conclude that CVB5 persists in the brain and heart after oral infection of CD1 mice. The relevance of viral persistence maybe related viral origin and the genetics.

Acknowledgements. This work was supported by the Norwegian Financial Mechanism, Mechanism EEA and Slovak Government and the State Budget of the Slovak Republic (SK 0082). 
Д. Стіпалова, М. Сойка, М. Борсаньйова, М. Бадурова,

Л. Марозова, 3. Шоботова, С. Бопегамаге

Збереження вірусної РНК у головному мозку мишей, експериментально інфікованих вірусом Коксакі В5

\section{Резюме}

Мета нашого дослідження полягала у тому, щоб прослідкувати, як вірусна РНК зберігається в окремих органах мишей, експериментально інфікованих деякими штамами вірусу Коксакі (ВК) В5, виділеному з різних джерел: із зразка пацієнта, навколишнього середовища і штаму прототипу вірусу. Методи. Мишей CD-1 інфікували ВКВ5 - прототипом Фолкнера $і$ двома вірусами, ідентифікованими як ВКВ5: перший виділено з оброблених відходів стічних вод, другий - із фекалій пацієнта. Вірусну РНК виявлено методом РТ-ПЛР $з$ використанням праймерів, специфичних для некодуючих 5'-ділянок ентеровірусів. Результаты. Ми спостерігали присутність РНК вірусу в головному мозку і сериі мишей, інфікованих ізолятом із фекалій пацієнта на 45-й день після зараження (PI). Висновки. Зроблено висновок стосовно того, що ВКВ5 зберігається в мозку і сериі після перорального зараження CD1 мишей. Ступінь вірусної стійкості можу бути пов 'язаний з походженням вірусу та його генетикою.

Ключові слова: вірус Коксакі В5, миші, мозок, стійкість.

Д. Стипалова, М. Сойка, М. Борсаньйова, М. Бадурова, Л. Марозова, 3. Шоботова, С. Бопегамаге

Сохранение вирусной РНК в головном мозге мышей, экспериментально инфицированных вирусом Коксаки В5

\section{Резюме}

Цель нашего исследования состояла в том, чтобы проследить, как вирусная РНК сохраняется в отдельных органах мышей, экспериментально инфицированных различными итаммами вируса Коксаки (ВК) В5, выделенными из разных источников: из образиа пациента, окружающей среды и итамма прототипа вируса. Методы. Мымей CD-1 инфицировали ВКВ5 - прототипом Фолкнера и двумя вирусами, идентифицированными как ВКВ5: первый выделен из обработанных отходов сточных вод, второй - из фекалий пациента. Вирусная РНК обнаружена методом РТ-ПЦР с использованием праймеров, специфичных для некодирующих 5' участков энтеровирусов. Результаты. Мы наблюдали присутствие РНК вируса в головном мозге и сердие мышей, инфицированных изолятом из фекалий пациента на 45-й день после заражения (PI). Выводы. Сделан вывод о том, что ВКВ5 сохраняется в мозге и сердие после перорального заражения CD1 мымей. Степень вирусной устойчивости может быть связана с происхождением вируса и его генетикой.

Ключевые слова: вирус Коксаки В5, мылии, мозг, устойчивость.

\section{REFERENCES}

1. Lindberg A. M., Polacek C. Molecular analysis of the prototype coxsackievirus B5 genome // Arch. Virol.-2000.-145, N 2.-P. 205-221.

2. Cree B. C., Bernardini G. L., Hays A. P., Lowe G. A fatal case of coxsackievirus B4 meningoencephalitis // Arch Neurol.2003.-60, N 1.-P.107-112.
3. Motusova J., Sojka M., Stipalova D. Standardization of plaque purification for coxsackieviruses // Coxsackieviruses and animal models: Basics and experiences of our laboratory / Ed. S. Bopegamage.-Bratislava: Asklepios, 2008.- P. 91-95.

4. Bopegamage S., Kovacova J., Vargova A., Motusova J., Petrovicova A., Benkovicova M., Gomolcak P., Bakkers J., van Kuppeveld F., Melchers W. J., Galama J. M. Coxsackie B virus infection of mice: inoculation by the oral route protects the pancreas from damage, but not from infection // J. Gen. Virol.2005.-86, pt 12.-P. 3271-3280.

5. Bopegamage S., Borsanyiova M., Vargova A., Petrovicova A., Benkovicova M., Gomolcak P. Coxsackievirus infection of mice I. Viral kinetics and histopathological changes in mice experimentally infected with coxsackieviruses B3 and B4 by the oral route // Acta Virol.-2003.-47, N 4.- P. 245-251.

6. De Leeuw N., Melchers W. J. G., Willemse D. F. M., Balk A. H. M. M., de Jonge N., Galama J. M. D. The diagnostic value of PCR for diagnosis of enteroviral infections // Serodiag. Immunother. Infect. Dis. J.-1994.-6, N 4.-P. 189-195.

7. Andreoletti L., Hober D., Becquart P., Belaich S., Copin M. C., Lambert $V$., Wattre P. Experimental CVB3-induced chronic myocarditis in two murine strains: evidence of interrelationships between virus replication and myocardial damage in persistent cardiac infection // J. Med. Virol.-1997.-52, N 2.- P. 206-214.

8. Kandolf R., Klingel K., Zell R., Selinka H. C., Raab U., Schneider-Brachert $W$., Bultmann B. Molecular pathogenesis of enterovirus-induced myocarditis: virus persistence and chronic inflammation // Intervirology.-1993.-35, N 1-4.-P. 140-151.

9. Klingel K., Hohenadi C., Canu A., Albrecht M., Seemann M., Mall $G$., Kandolf $R$. Ongoing enterovirus-induced myocarditis is associated with persistent heart muscle infection: quantitative analysis of virus replication, tissue damage, and inflammation // Proc. Natl Acad. Sci. USA.-1992.-89, N 1.-P. 314-318.

10. Chapman N. M., Kim K.-S. Persistent coxsackievirus infection: Enterovirus persistence in chronic myocarditis and dilated cardiomyopathy // Curr. Top. Microbiol. Immunol.-2008.- 323.P. 275-292.

11. Klingel $K$. Molecular biologic detection of virus infection myocarditic and dilated cardiomyopathy // Myocarditis from bench and bedside / Ed. L. T. Coopers, Jr.-New Jersey: Humana press, 2003.-P. 295-324.

12. Gow J. W., Behan W. M. H., Cash P., Simpson K., Behan P. O. Genomic and template RNA transcription in a model of persistent enteroviral infection // J. NeuroVirol.-1997.-3, N 1.P. 76-82.

13. Pelletier I., Couderc T., Borzakian S., Wyckoff E., Crainic R., Ehrenfeld E., Colbere-Garapin F. Characterization of persistent poliovirus mutants selected in human neuroblastoma cells // Virology-1991.-180, N 2.-P. 729-737.

14. Tracy $S$. The genome of the Group B coxsackieviruses // Coxsackieviruses - a general update / Eds M. Bendinelli, H. Friedman.-New York: Plenum Publ., 1988.-P. 19-33.

15. Dunn J. J., Bradrick S. S., Chapman N. M., Tracy S. M., Romero $J$. $R$. The stem loop II within the 5 ' nontranslated region of clinical coxsackievirus B3 genomes determines cardiovirulence phenotype in a murine model // J. Infect. Dis-2003.-187, N 10.P. 1552-1561.

UDC 57.017.2 + 578.835.1

Received 10.01.11 